\title{
MOLECULAR MODELLING OF ACRIDINE OXIDATION BY PEROXYACIDS
}

\author{
Volodymyr Dutka ${ }^{1,}{ }^{*}$, Yaroslav Kovalskyi ${ }^{1}$, Olena Aksimentyeva ${ }^{1}$, \\ Nadia Tkachyk ${ }^{1}$, Nataliia O shchapovska ${ }^{1}, \mathrm{H}$ alyna Halechko ${ }^{1}$
}

https://doi.org/10.23939/chcht13.03.334

\begin{abstract}
The optimal geometric structure and reactivity of some peroxyacids, acridine and products of their interaction were calculated by quantum-chemical methods. It was found that the heat of formation of peroxyacids (PA) and carboxylic acids (CA) grow with increasing length of a hydrocarbon radical. The dependencies of the area of PA and molecules of CA on the number of carbon atoms in the molecules are linear. The potentials of ionization of all studied PA are close and lie within the range of $11.22-11.39 \mathrm{eV}$ depending on the calculation methods. The theoretically calculated dipole moments of acids, acridine, peroxyacids, and $N$-oxide of acridine are in good accordance with experimental values, which indicate the correctness of our calculations. Theoretical calculated values of the heats of formation $\left(\Delta H_{f}^{0}\right)$ of peroxyacids and acridine are in good accordance with the values obtained by thermo-chemical methods. Calculations indicate that the size of the hydrocarbon radical practically does not affect the value of $\Delta H^{0}$ exp. The results of quantum chemical calculations for the oxidation reaction of acridine may be useful for prediction of other mechanisms of oxidative processes.
\end{abstract}

Keywords: peroxyacids, quantum-chemical calculations, oxidation, acridine, heat of formation.

\section{Introduction}

Organic peroxy-compounds are widely used as a source of free radicals, oxidizing agents, intermediates in organic synthesis, disinfectant agent, etc. [1-3]. Peroxyacids interact with sulfides, amines, ethylene hydrocarbons, demonstrate mild oxidative effect, and give valuable products.

The information about the structure and electronic properties of molecules is important for successful application of peroxide compounds. Quantum-chemical calculations are used for this. We can predict the reactivity,

\footnotetext{
${ }^{1}$ Ivan Franko National University of Lviv,

6, Kyryla\&Mefodia St., 79005 Lviv, Ukraine

*vdutka@ukr.net

(C) Dutka V., Kovalskyi Ya., Aksimentyeva O., Tkachyk N., Oshchapovska N., Halechko H., 2019
}

calculate the thermodynamic parameters and the optimal structure of peroxide compounds using them $[4,5]$.

The aim of our work was quantum-chemical calculations for the reaction of acridine oxidation by peroxyacids. Often, these reactions are used to produce $\mathrm{N}$-oxides. Oxidation reactions of nitrogen-containing compounds by different oxidants allow receiving different conducting polymers [6,7], biologically active compounds $[8,9]$ and apply these processes to neutralize substances harmful to the environment [10].

\section{Experimental}

The results of the theoretical calculations using quantum chemical methods are shown in this work. These are standard heats of formation $\left(\Delta H_{f}^{0}\right)$, ionization potential $\left(I_{X}\right)$, energy of higher occupied molecular orbital (HOMO) and a lower unoccupied molecular orbital (LUMO), dipole moments $(D)$, volume $(V)$ and area $(S)$ of molecules of certain peroxyacids (PA), carboxylic acids (CA), acridine and its $\mathrm{N}$-oxides.

Chemical potential $(\mu)$ and rigidity of the molecule $(\eta)$ were calculated by the energy of higher occupied molecular orbital $\left(E_{\mathrm{HOMO}}\right)$ and a lower unoccupied molecular orbital $\left(E_{\mathrm{LUMO}}\right)$ :

$$
\mu=\left(E_{\mathrm{HOMO}}+E_{\mathrm{LUMO}}\right) / 2 \text {; and } \eta=\left(E_{\mathrm{HOMO}}-E_{\mathrm{LUMO}}\right)
$$

As is known, the frontier orbitals method, proposed by Fukui, identifies the relative reactive activity of the compounds by the energy of the molecular orbitals of $E_{\mathrm{HOMO}}$ and $E_{\mathrm{LUMO}}[11,12]$. The $E_{\mathrm{HOMO}}$ causes the interaction of the molecule with the electron acceptors, and the $E_{\mathrm{LUMO}}$ - electron donors. The positive energy of $E_{\mathrm{LUMO}}$ causes the nucleophile properties of the molecules, and the negative - the electrophilic ones.

All quantum-chemical calculations were carried out using semi-empirical methods implemented in the program MOPAC2016 [13] and using the graphical interface Winmostar [14]. The calculations were carried out using the methods AM1, PM3, PM6, PM7, MNDO, and RM1. All calculations were conducted for the gas phase. Based on the performed calculations, the heats of the reaction were obtained, and the possible mechanism of the reaction was predicted. 


\section{Results and Discussion} formula:

Calculations for peroxyacids (PA) of the general

$$
\mathrm{R}-\mathrm{C}(\mathrm{O})-\mathrm{O}-\mathrm{O}-\mathrm{H}
$$

were carried out, were $\mathrm{R}$ is equal to: $\mathrm{CH}_{3}-(\mathbf{I}) ; \mathrm{CH}_{3}-\mathrm{CH}_{2}-$ (II); $\mathrm{CH}_{3}-\left(\mathrm{CH}_{2}\right)_{2}-\left(\right.$ III) $; \mathrm{CH}_{3}-\left(\mathrm{CH}_{2}\right)_{4-}$ (IV); $\mathrm{CH}_{3-}$ $\left(\mathrm{CH}_{2}\right)_{5}-(\mathrm{V}) ; \mathrm{CH}_{3}-\left(\mathrm{CH}_{2}\right)_{6}-(\mathrm{VI}) ; \mathrm{CH}_{3}-\left(\mathrm{CH}_{2}\right)_{7}-(\mathrm{VII})$; $\mathrm{CH}_{3}-\left(\mathrm{CH}_{2}\right)_{8}-(\mathbf{V I I I}) ; \mathrm{C}_{6} \mathrm{H}_{5}-(\mathbf{I X})$.

Physico-chemical parameters were calculated for the studied peroxyacids using semiempirical method AM1. They are presented in Table 1.
The heats of formation of peroxyacids coincide with the results of thermo-chemical data. Quantumchemical calculations for peroxybenzoic acid (PBA) and benzoic acid (BA) were different from the corresponding values for aliphatic peroxyacids and their corresponding carboxylic acids.

The heat of formation of peroxyacids (PA) and carboxylic acids (CA) grow with increasing length of a hydrocarbon radical. The numerical values of the heat of formation and dipole moments of the PA and CA, with different number of carbon atoms in molecules $(N)$ are given in Tables 2 and 3.

Table 1

Physico-chemical parameters of peroxyacids. Calculation method - AM1

\begin{tabular}{|c|c|c|c|c|c|c|c|c|c|}
\hline \multirow{2}{*}{ Parameters } & \multicolumn{9}{|c|}{ Peroxyacids } \\
\cline { 2 - 10 } & I & II & III & IV & V & VI & VII & VIII & IX \\
\hline$-\Delta H_{f}^{0}, \mathrm{~kJ} / \mathrm{mol}$ & 298.69 & 324.48 & 352.91 & 410.16 & 436.30 & 462.32 & 496.69 & 516.70 & 152.26 \\
\hline$D$, Debye & 2.443 & 2.515 & 2.573 & 2.607 & 2.658 & 2.396 & 2.675 & 2.567 & 3.241 \\
\hline$E_{\text {HOMO }}, \mathrm{eV}$ & -11.383 & -11.258 & -11.274 & -11.247 & -11.236 & -11.089 & -11.022 & -10.999 & -10.239 \\
\hline$E_{\mathrm{LUMO}}, \mathrm{eV}$ & 0.589 & 0.640 & 0.635 & 0.637 & 0.649 & 0.941 & 0.648 & 0.657 & -0.671 \\
\hline$\mu, \mathrm{eV}$ & -5.986 & -5.307 & -5.319 & -5.303 & -5.294 & -5.074 & -5.187 & -5.171 & -5.455 \\
\hline$\eta, \mathrm{eV}$ & 11.997 & 11.898 & 11.872 & 11.873 & 11.885 & 12.030 & 11.670 & 11.674 & 9.568 \\
\hline$S, \AA^{2}$ & 102.9 & 121.7 & 141.6 & 181.9 & 201.7 & 217.1 & 241.8 & 255.6 & 162.2 \\
\hline$V, \AA^{3}$ & 85.51 & 106.7 & 128.7 & 173.0 & 195.2 & 215.2 & 238.9 & 259.5 & 155.8 \\
\hline
\end{tabular}

Table 2

The dependence of the heats of formation of aliphatic peroxyacids $\left(\Delta H_{f}^{0}, \mathrm{~kJ} / \mathrm{mol}\right)$ and dipole moments $(D)$ on number of carbon atoms $(N)$ in a molecule, calculated using various semi-empirical methods

\begin{tabular}{|c|c|c|c|c|c|c|c|c|c|}
\hline$N$ & 2 & 3 & 4 & 5 & 6 & 7 & 8 & 9 & 10 \\
\hline$-\Delta H_{f}^{0}$, AM1 & 298,69 & 324.48 & 352.91 & 381.92 & 410.16 & 439.30 & 462.32 & 496.69 & 516.72 \\
\hline$-\Delta H_{f}^{0}$, PM3 & 325.72 & 344.51 & 369.16 & 389.78 & 414.45 & 435.17 & 454.76 & 480.60 & 498.71 \\
\hline$-\Delta H_{f}^{0}$, PM6 & 283,39 & 300.12 & 322.06 & 342.73 & 362.91 & 384.45 & 403.94 & 426.21 & - \\
\hline$-\Delta H_{f}^{0}$, PM7 & 307.06 & 325.51 & 347.05 & 368.08 & 389.06 & 410.85 & 430.58 & 453.58 & 471.66 \\
\hline$-\Delta H_{f}^{0}$, RM1 & 321.03 & 342.19 & 363.88 & 384.66 & 403.48 & 426.44 & 441.90 & 468.21 & 479.92 \\
\hline$-\Delta H_{f}^{0}$, MNDO & 309.67 & 331.44 & 351.29 & 371.05 & 390.90 & 410.55 & 424.66 & 450.07 & 460.83 \\
\hline$-\Delta H_{f}^{0}$, exp. & - & - & - & - & 428.3 & 448.9 & 469.5 & 490.1 & 510.7 \\
\hline$D$, RM1 & 2.55 & 2.53 & 2.59 & 2.58 & 2.53 & 2.60 & 2.43 & 2.61 & 2.42 \\
\hline$D$ exp. & - & - & - & - & - & - & - & 2.37 & 2.27 \\
\hline
\end{tabular}

Table 3

The dependence of the heats of formation of aliphatic acids $\left(\Delta H_{f}^{0}, \mathrm{~kJ} / \mathrm{mol}\right)$ and dipole moments $(D)$ on the number of carbon atoms $(N)$ in a molecule, calculated using various semi-empirical methods

\begin{tabular}{|c|c|c|c|c|c|c|c|c|c|}
\hline$N$ & 2 & 3 & 4 & 5 & 6 & 7 & 8 & 9 & 10 \\
\hline$-\Delta H_{f}^{0}$, AM1 & 431.24 & 456.69 & 485.55 & 514.09 & 542.79 & 571.35 & 594.53 & 628.86 & - \\
\hline$-\Delta H_{f}^{0}$, PM3 & 426.51 & 445.32 & 467.94 & 490.48 & 513.27 & 535.96 & 555.43 & 581.35 & - \\
\hline$-\Delta H_{f}^{0}$, PM6 & 423.67 & 440.22 & 452.31 & 482.85 & 503.80 & 524.65 & 544.28 & 566.48 & - \\
\hline$-\Delta H_{f}^{0}$, PM7 & 427.79 & 445.53 & 468.51 & 489.35 & 510.95 & 532.28 & 550.68 & 575.01 & 596.36 \\
\hline$-\Delta H_{f}^{0}$, RM1 & 423.51 & 443.44 & 466.93 & 487.69 & 508.62 & 529.48 & 544.71 & 571.26 & 591.15 \\
\hline$-\Delta H_{f}^{0}$, MNDO & 422.62 & 445.06 & 461.61 & 481.36 & 501.08 & 520.84 & 538.16 & 560.36 & 580.13 \\
\hline$-\Delta H_{f}^{0}$, exp. & 433.0 & 455.8 & 475.9 & 491 & 512 & 536.5 & 554.5 & 575.6 & 624.2 \\
\hline$D$, RM1 & 1.766 & 1.766 & 1.755 & 1.72 & 1.75 & 1.73 & 1.86 & 1.73 & 1.954 \\
\hline$D$, exp. & 1.77 & 1.75 & 1.58 & 1.74 & - & - & - & - & - \\
\hline
\end{tabular}




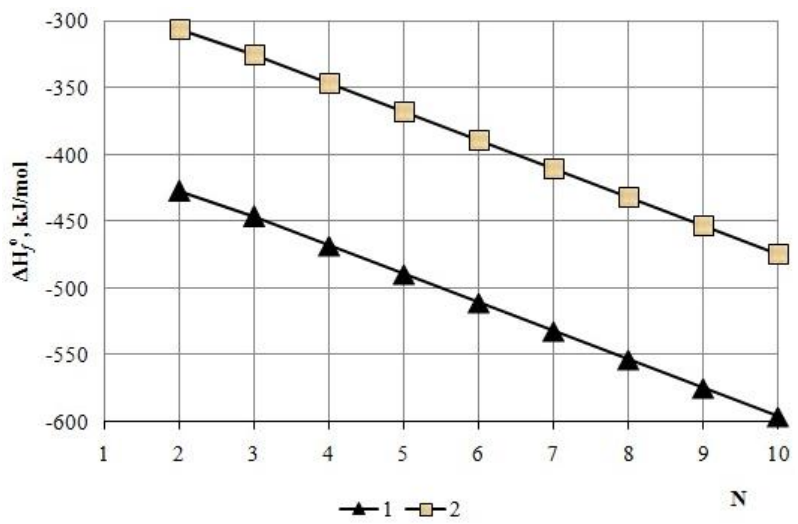

Fig. 1. The dependence of the heat of formation $\left(\Delta H_{f}^{0}\right)$ for carboxylic acids (1) and peroxyacids (2) on the number of carbon atoms $(N)$ in molecules. Method of Calculation PM7

The dependencies of the heat of formation on the number of carbon atoms in molecule of peroxyacids or carboxylic acid calculated by different semiempirical methods are linear (Fig. 1). The numerical values of the heat of formation of peroxyacids or carboxylic acids with different values of $\mathrm{N}$ can be predicted with these dependencies.

The $E_{\mathrm{HOMO}}$ and $E_{\mathrm{LUMO}}$ are similar. Those characterize the oxidation-reducing properties of PA for compounds I-VIII. For peroxybenzoic acid, those differ slightly from the parameters for aliphatic peroxyacids. The parameters $\mu$ and $\eta$ for peroxyacids I-VIII are almost the same (Table 1).

The numerical values of the areas and volumes of the compounds depend on their structure. The dependencies of the molecule area $S$ of PA and CA on the number of carbon atoms in the molecules are linear. The difference between the areas of molecules of peroxyacid and carboxylic acid with the identical number of $N$ calculated by various methods is within the range of $11.03-11.97 \AA^{2}$. This numerical value corresponds to the area of the oxygen atom in PA. Dependencies of volumes of molecules of PA and CA on the number of carbon atoms in molecules are linear too. The values of the volume of oxygen atom determined by the differences of PA and CA volumes are within the limits of 11.01-11.87 $\AA^{3}$. The difference between the areas of PA containing $N$ and $N-1$ atoms of carbon in the molecule will give the area of the $\mathrm{CH}_{2}$ group in the investigated compounds. The numerical values of the $\mathrm{CH}_{2}$ group area, depending on the calculation method, are within the range of 18.71$19.51 \AA^{2}$. The volumes of the $\mathrm{CH}_{2}$ group are 21.25$22.04 \AA^{3}$. The potentials of ionization of all studied PA are close, and they are within the range of 11.220 $11.389 \mathrm{eV}$ depending on the calculation methods. Numerical values of $I_{X}$ for carboxylic acids are similar to the values of PA and are changing within the limits of $11.054-11.492 \mathrm{eV}$.

The dipole moments of all studied PA and the structures of molecules of peroxyacids are similar. All PA in gas phase or in "inert" solvents form a compound with an intramolecular hydrogen bond (Fig. 2). Moreover, the hydrogen atom $\mathrm{H}(1)$ is bounding with oxygen of the carboxylic group $\mathrm{O}(5)$. The energy of hydrogen bond found based on the conformational analysis at the rotation of the $\mathrm{OH}$ group is $12.9 \mathrm{~kJ} / \mathrm{mol}$ [15].



Fig. 2. The optimal molecular structure of peroxyacid VI

The length of $\mathrm{O}-\mathrm{O}$ bond, according to the quantumchemical calculations, is $1.399 \AA$. The length of this bond determined from $\mathrm{X}$-ray diffraction data of peroxynonanic acid is equal to $1.442 \AA$ [16]. The length of bond of the carbonyl group is $1.231 \AA$ and the results of the theoretical calculations provide the value of $1.229 \AA$. The $\mathrm{C}-\mathrm{O}-\mathrm{O}$ angle obtained as a result of $\mathrm{X}$-ray diffraction is $112.0^{\circ}$, whereas according to the quantum-chemical calculations it is $129.5^{\circ}$. Thus, experimental values and results of theoretical studies are in agreement. Small differences can be explained by the fact that X-ray diffraction was conducted for crystalline specimens in a solid state, while quantum-chemical calculations were performed for a molecule in the gas phase.

Valuable information can be obtained by investigating the partial charges on the atoms of PA. Partial charges on atoms calculated by semiempirical quantum-chemical methods AM1 are presented in the Table 4.

The atom $\mathrm{H}(1)$ has a deficiency of electron density, which indicates its "acid" character. The acidity of PA is less than for the corresponding carboxylic acids. The values of $\mathrm{pKa}$ for peroxyacids are within the limits of 7.01-8.7 [17]. The partial charges are almost identical at atoms of oxygen in peroxide group. It should be noted that the partial charges on the oxygen atoms of $\mathrm{O}(2)$ and $\mathrm{O}(3)$ in molecules of hydroperoxide are different, unlike molecules of PA [18]. 
The attack on the reaction center in the reactions of electrophilic oxidation is performed by an oxygen atom $\mathrm{O}(2)$. This statement is true for reactions involving hydroperoxides [2]. The attack on a multiple bond or a nitrogen atom in the case of peroxyacids can be carried out by $\mathrm{O}(2)$ and $\mathrm{O}(3)$ atom. The carbonyl group in molecules of PA is strongly polarized (Table 6). A partial charge on all other atoms for the investigated PA does not change with the radical change near the peroxide group of the PA. The partial charges for the molecule of peroxybenzoic acid are different from the parameters calculated for all aliphatic PA.

The infrared spectra of the PA calculation allowed detecting the bands characteristic of these compounds. The characteristic band in the IR spectrum of the PA is the absorption at $3280 \mathrm{~cm}^{-1}$, which corresponds to the absorption frequency of the $\mathrm{OH}$ group, bound by the intramolecular hydrogen bond. In addition, the absorption band at $2000 \mathrm{~cm}^{-1}$ is observed in the spectrum. This corresponds to the oscillation of the group $\mathrm{C}=\mathrm{O}$ of PA. The absorption band of the $\mathrm{O}-\mathrm{O}$ bond in the theoretically calculated spectrum is observed at $1500 \mathrm{~cm}^{-1}$. In the spectrum of the PDA solution in carbon tetrachloride, the absorption band of the peroxide bond is observed at the wavelength of $865 \mathrm{~cm}^{-1}$. The absorption band at $3280 \mathrm{~cm}^{-1}$ corresponds to the absorption frequency of the $\mathrm{OH}$-group associated with the intramolecular hydrogen bond, which coincides with the value theoretically calculated. The absorption band at $1760 \mathrm{~cm}^{-1}$ corresponds to the absorption of the carbonyl group $\mathrm{C}=\mathrm{O}$, whereas, for the calculated spectrum, the quantum-chemical absorption method is observed at $2000 \mathrm{~cm}^{-1}$.

In our opinion, some discrepancy between theoretically calculated and experimentally calculated wavelengths in IR spectra can be explained by the fact that those theoretical calculations of IR spectra are carried out for an individual molecule in a vacuum, while experi- mental measurements were carried out in a solution of carbon tetrachloride. It should be noted that according to the obtained data; the intra-molecular hydrogen bond is characterized by considerable strength. Spectroscopic studies in the wavelength range from 4000 to $2500 \mathrm{~cm}^{-1}$ for solutions of PDA with different concentrations practically do not change the position and nature of absorption bands. The change in the PDA concentration from 0.0125 to $0.2 \mathrm{~mol} / \mathrm{l}$ in a solution of carbon tetrachloride gives a proportional increase in the optical density of the $3280 \mathrm{~cm}^{-1}$ band. This suggests that at the moderate concentrations of the peroxyacid molecules exist in a monomer state with intramolecular hydrogen bonds $[19,20]$.

Quantum-chemical calculations for acridine (AN) and acridine $N$-oxide (OAN) were carried out by semiempirical methods. Optimal geometric structures of acridine and acridine $N$-oxide are given in Fig. 3 .

According to quantum-chemical calculations, the acridine and acridine-10-oxide molecules are flat. All flat angles in both molecules are $120^{\circ}$. The heat of formation of acridine and acridine-10-oxide and other parameters calculated by semiempirical methods AM1, PM3, PM7, RM1, and MNDO are given in Tables 5 and 6.

The calculated heats of formation of acridine are within the range from -213.17 to $-299.61 \mathrm{~kJ} / \mathrm{mol}$. The value of $\Delta H_{f}^{0}$ which was found via thermo-chemical method, is equal to $-273.9 \pm 2.0 \mathrm{~kJ} / \mathrm{mol}$, and corresponds well to the values calculated theoretically. The theoretically calculated dipole moments of acids, acridine, peroxyacids, and $\mathrm{N}$-oxide of acridine are in good agreement with experimental values [21], which may indicate the correctness of our calculations. The values of partial charges on atoms can give important information about the reactivity of the molecules. The results of such calculations are presented in Table 7.

Table 4

Partial charges on the peroxyacids atoms (by Mulliken)

\begin{tabular}{|c|c|c|c|c|c|c|c|}
\hline \multirow{2}{*}{ Peroxyacid } & \multicolumn{7}{|c|}{ Atom label } \\
\cline { 2 - 8 } & $\mathrm{H}(1)$ & $\mathrm{O}(2)$ & $\mathrm{O}(3)$ & $\mathrm{C}(4)$ & $\mathrm{O}(5)$ & $\mathrm{C}(6)$ & $\mathrm{C}(7)$ \\
\hline I & 0.203 & -0.156 & -0.166 & 0.335 & -0.317 & -0.223 & - \\
\hline II & 0.202 & -0.156 & -0.170 & 0.322 & -0.316 & -0.158 & -0.214 \\
\hline III & 0.202 & -0.157 & -0.165 & 0.321 & -0.317 & -0.158 & -0.159 \\
\hline IV & 0.203 & -0.156 & -0.161 & 0.365 & -0.325 & -0.158 & -0.158 \\
\hline V & 0.201 & -0.156 & -0.168 & 0.325 & -0.318 & -0.159 & -0.158 \\
\hline VI & 0.202 & -0.156 & -0.170 & 0.323 & -0.318 & -0.157 & -0.152 \\
\hline VII & 0.202 & -0.157 & -0.165 & 0.321 & -0.317 & -0.158 & -0.158 \\
\hline VIII & 0.211 & -0.137 & -0.168 & 0.269 & -0.325 & -0.157 & -0.156 \\
\hline IX & 0.213 & -0.166 & -0.132 & 0.316 & -0.330 & -0.123 & -0.067 \\
\hline
\end{tabular}

Notes: Atom labels correspond to the numbers in Fig. 2. Calculation method AM1. 


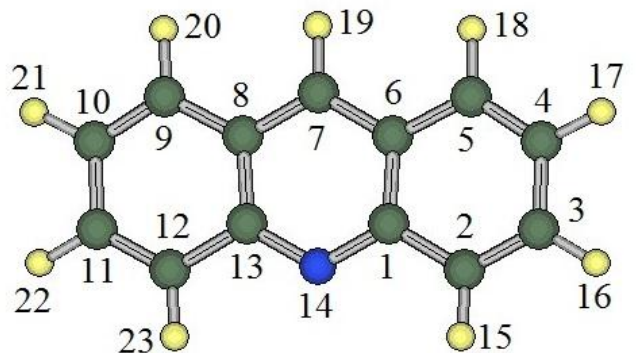

a)

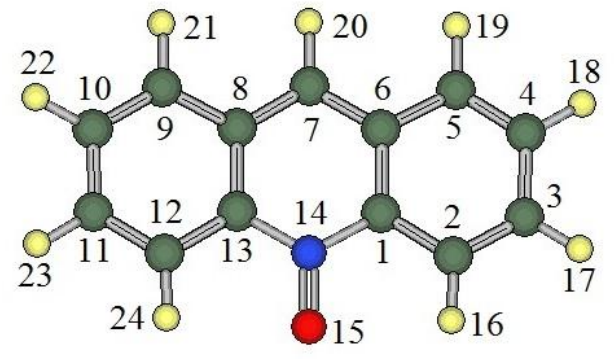

b)

Fig. 3. Optimal geometric structure of acridine (a) and its oxidation product - acridine- $N$-oxide (b)

Table 5

Physico-chemical parameters for acridine calculated using various semi-empirical methods

\begin{tabular}{|c|c|c|c|c|c|}
\hline \multirow{2}{*}{ Parameter } & \multicolumn{3}{|c|}{ Method of calculation } \\
\cline { 2 - 6 } & AM1 & PM3 & PM7 & RM1 & MNDO \\
\hline$-\Delta H_{f}^{0}, \mathrm{~kJ} / \mathrm{mol}$ & 297.59 & 268.91 & 299.61 & 260.96 & 1.871 \\
\hline$D$, Debye & 1.681 & 1.681 & 1.456 & -8.719 & -9.102 \\
\hline$E_{\mathrm{HOMO}}, \mathrm{eV}$ & -8.949 & -8.974 & -8.854 & -0.175 & -0.394 \\
\hline$E_{\mathrm{LUMO}}, \mathrm{eV}$ & -0.604 & -0.807 & -1.232 & -4.447 & -4.748 \\
\hline$\mu, \mathrm{eV}$ & -4.777 & -4.891 & -5.044 & 8.532 & 8.708 \\
\hline$\eta, \mathrm{eV}$ & 8.345 & 8.167 & 7.622 & 208.67 & 212.04 \\
\hline$S, \AA^{2}$ & 209.32 & 208.90 & 209.38 & 214.10 & 218.76 \\
\hline$V, \AA^{3}$ & 215.07 & 214.44 & 215.51 & 8.719 & 9.102 \\
\hline$I_{X}, \mathrm{eV}$ & 8.949 & 8.974 & 8.854 & & \\
\hline
\end{tabular}

Table 6

Physico-chemical parameters for acridine- $N$-oxide calculated using various semi-empirical methods

\begin{tabular}{|c|c|c|c|c|c|}
\hline \multirow{2}{*}{ Parameter } & \multicolumn{3}{|c|}{ Method of calculation } \\
\cline { 2 - 6 } & AM1 & PM3 & PM7 & RM1 & MNDO \\
\hline$-\Delta H_{f}^{0}, \mathrm{~kJ} / \mathrm{mol}$ & 288.64 & 242.73 & 251.31 & 3.092 & 240.36 \\
\hline$D, \mathrm{Debye}$ & 3.149 & 3.376 & 2.82 & -8.489 & -8.898 \\
\hline$E_{\mathrm{HOMO}}, \mathrm{eV}$ & -8.751 & -8.882 & -8.516 & -0.049 & -0.022 \\
\hline$E_{\mathrm{LUMO}}, \mathrm{eV}$ & -0.115 & -0.365 & -0.796 & -4.369 & -4.460 \\
\hline$\mu, \mathrm{eV}$ & -4.433 & -4.259 & -4.656 & 8.440 & 8.876 \\
\hline$\eta, \mathrm{eV}$ & 8.636 & 8.517 & 7.49 & 215.12 & 219.15 \\
\hline$S, \AA^{2}$ & 215.96 & 215.43 & 215.40 & 225.04 & 230.08 \\
\hline$V, \AA^{3}$ & 225.82 & 225.49 & 225.39 & 8.489 & 8.898 \\
\hline$I_{X}, \mathrm{eV}$ & 8.75 & 8.593 & 8.516 & & \\
\hline
\end{tabular}

Table 7

Partial charges on the atoms (by Mulliken)

of the studied molecules of acridine and acridine $\mathrm{N}$-oxide

\begin{tabular}{|c|c|c|c|c|c|}
\hline Atom label & Acridine & Acridine- $N$-oxide & Atom label & Acridine & Acridine- $N$-oxide \\
\hline 1C & 0.003 & -0.026 & $8 \mathrm{C}$ & -0.066 & -0.026 \\
\hline 2C & -0.099 & -0.105 & $9 \mathrm{C}$ & -0.116 & -0.116 \\
\hline 3C & -0.127 & -0.123 & $10 \mathrm{C}$ & -0.123 & -0.123 \\
\hline 4C & -0.123 & -0.123 & $11 \mathrm{C}$ & -0.127 & -0.123 \\
\hline 5C & -0.116 & -0.116 & $12 \mathrm{C}$ & -0.099 & -0.105 \\
\hline 6C & -0.066 & -0.026 & $13 \mathrm{C}$ & 0.003 & -0.026 \\
\hline 7C & -0.095 & -0.126 & $14 \mathrm{~N}$ & -0.105 & 0.200 \\
\hline & & & $15 \mathrm{O}$ & - & -0.350 \\
\hline
\end{tabular}

Notes: The numbers of the atoms correspond to the numbers in Fig. 3. Method of calculation AM1. 
Partial charges in the molecules of acridine and $\mathrm{N}$-oxide of acridine for carbon atoms, which are in the identical positions, are almost identical. At the atom of nitrogen in the molecule of acridine, the partial charge is -0.105 , and in the $N$-oxide of acridine, the corresponding value becomes positive and equal to
0.200 . The oxygen atom in the $\mathrm{N}$-oxide of acridine has a partial charge of -0.350 , which indicates the polarization of the $\mathrm{N}-\mathrm{C}$ bond.

The thermal effects of the reaction based on the quantum-chemical calculations were obtained. The scheme of oxidation reaction of acridine:<smiles></smiles>

Table 8

The heat of formation of molecules and thermal effect of acridine oxidation by peroxydecanoic acid, calculated using different semiempirical methods

\begin{tabular}{|c|c|c|c|c|c|}
\hline \multirow{2}{*}{ Method of calculation } & \multicolumn{3}{|c|}{ The heat of formation of molecules $\Delta H_{f}^{0}, \mathrm{~kJ} / \mathrm{mol}$} & $\begin{array}{c}\text { Thermal effect of } \\
\text { acridine oxidation } \\
\Delta H_{\text {exp }}, \mathrm{kJ} / \mathrm{mol}\end{array}$ \\
\cline { 2 - 6 } & Acridine & Peroxydecanoic acid & Decanoic acid & Acridine- $N$-oxide & -149.6 \\
\hline AM1 & 297.5 & -516.7 & -657.4 & 288.6 & -131.7 \\
\hline PM3 & 268.9 & -498.7 & -604.2 & 242.7 & -164.1 \\
\hline PM7 & 299.6 & -471.6 & -587.4 & 251.3 & -150.7 \\
\hline RM1 & 260.9 & -479.9 & -587.4 & 240.3 & -102.8 \\
\hline MNDO & 213.7 & -460.8 & -592.2 & - & - \\
\hline
\end{tabular}

Table 9

Thermal effect of acridine oxidation by various peroxyacids, calculated using different semiempirical methods

\begin{tabular}{|c|c|c|c|c|c|c|c|c|c|}
\hline \multirow{2}{*}{$\begin{array}{c}\text { Method of } \\
\text { calculation }\end{array}$} & \multicolumn{8}{|c|}{ Thermal effect of acridine oxidation by various peroxyacids, $-\Delta H_{\text {exp }}^{0}, \mathrm{~kJ} / \mathrm{mol}$} \\
\cline { 2 - 10 } & I & II & III & IV & V & VI & VII & VIII & IX \\
\hline AM1 & 141.14 & 141.15 & 141.58 & 140.95 & 140.99 & 141.15 & 141.11 & - & 141.44 \\
\hline PM3 & 126.06 & 126.99 & 124.97 & 125.01 & 126.97 & 126.86 & 126.93 & - & 125.60 \\
\hline PM7 & 169.03 & 169.32 & 168.30 & 170.19 & 169.72 & 168.40 & 169.79 & 164.10 & 169.00 \\
\hline RM1 & 145.95 & 144.74 & 146.53 & 148.61 & 146.51 & 146.28 & 146.52 & - & 146.28 \\
\hline
\end{tabular}

The heat of reaction of acridine by peroxydecanoic acid (PDA) using various methods calculated by the Hess equation is given in Table 8.

The numerical values of the heat of formation of PDA, decanoic acid and acridine well coincide with the corresponding values of $\Delta H_{f}^{0}$ found thermo-chemically $[22,23]$. The thermo-chemical data for $\mathrm{N}$-oxide of acridine are absent in literature. According to quantumchemical calculations, the numerical values of $\Delta H_{f}^{0}$ are within the range of $217.4-288.6 \mathrm{~kJ} / \mathrm{mol}$. The reaction of oxidation of acridine is exothermic.

The thermal effect was calculated by different semiempirical methods. For this reaction, it is from -102.8 to $-164.1 \mathrm{~kJ} / \mathrm{mol}$. The data on the thermal effects of the acridine oxidation by various peroxyacids, calculated using different semiempirical methods are presented in Table 9. Calculations indicate that the size of the hydrocarbon radical practically does not affect the value of $\Delta H_{\text {exp. }}^{0}$ Using the AM1 method, the numerical values of $\Delta H_{\text {exp }}^{0}$ are equal to $140.95-141.44 \mathrm{~kJ} / \mathrm{mol}$. In the case of use of peroxybenzoic acid as an oxidant, the thermal effect of the process is also $-141.44 \mathrm{~kJ} / \mathrm{mol}$.

\section{Conclusions}

Quantum-chemical calculations allow to find the optimal geometric structure of molecules and predict the reactivity of peroxyacids. In our work, optimal geometric structures, the heats of formation of the starting compounds and the products of the reaction of acridine oxidation by peroxyacids were calculated. The obtained results can be considered reliable due to the good correspondence between the theoretical and calculated 
values. The results of quantum chemical calculations for the oxidation reaction of acridine may be useful for prediction of other mechanisms of oxidative processes.

\section{References}

[1] Prylezhaeva E. (Ed.): Reaktsiya Prilezhaeva. Electrophil'noe Okislenie. Nauka, Moskva 1974.

[2] Tolstikov G. (Ed): Reaktsii Hydroperoksidnogo Okisleniya. Nauka, Moskva 1976.

[3] Antonovsky V., Khursan S. (Eds.): Phisicheskaya Khimiya Organicheskich Peroksidov. ICC "Akademkniga", Moskva 2003. [4] Soloviev M., Soloviev M. (Eds.): Computernaya Khimiya. , Solon. Press, Moskva 2005.

[5] Clark T. (Ed.): A Handbook of Computational Chemistry. Wiley-Interscience, New York 1985.

[6] Blinova N., Stejkal J., Trchova M. et al.: Polymer, 2009, 50, 50. https://doi.org/10.1016/j.polymer.2008.10.040

[7] Stejskal J., Gilbert R.: Pure Appl. Chem., 2002, 74, 857. https://doi.org/10.1351/pac200274050857

[8] Dutka V., Matsyuk N., Dutka Yu.: Russ. J. Phys. Chem. A, 2011, 85, 45. https://doi.org/ 10.1134/S0036024411010079

[9] Haynes A. (Ed.): Methods of Oxidation of Organic Compounds. Academic Press Inc., London 1985.

[10] Thomsen A.: Water Res., 1998, 32, 136.

https://doi.org/10.1016/S0043-1354(97)00200-5

[11] Parr R., Yang W.: Density-functional theory of atoms and molecules. Oxford University Press, New York 1989.

[12] Jasinski R., Baranski A.: J. Mol. Struc.-THEOCHEM, 2010,

949, 8. https://doi.org/10.1016/j.theochem.2010.02.023

[13] Stewart J. (Ed.): Program Package MOPAC2016.

http://www.openmopac.net

[14] Senda N. (Ed.): Program Package Winmostar.

http://winmostar.com

[15] Dutka V., Derkach Y Savitska O. and Kovalsky Y.: Visnuk

Lviv Nats. Univ., 2007, 48, 166.

[16] Kitaigorodskii A., Zorkii P., Belskii V.: Stroenie

Organicheskogo Veshchestva. Dannye Strukturnych Issledovanii 1929-1970. Nauka, Moskva 1980.

[17] Antonovsky V. (Ed.): Organicheskie Peroksidnye Initsiatory. Khimiya, Moskva 1972.
[18] Dutka V., Shchedry V., Gritselyak T., Kovalskyi Ya.: Visnuk Lviv Nats. Univ., 2013, 54, 358.

[19] Shriner R., Fuson R., Curtin D. et al.: The Systematic Identification of Organic Compounds. A Laboratory Manual. John Wiley \& Sons, NY-Toronto 1980.

[20] Zhukovskii V.: Russ. J. Phys. Chem., 1983, 57, 2353.

[21] Osipov O., Minkin V. (Eds.): Spravochnik po Dipolnym Momentam. Vyschaja schkola, Moskva 1965.

[22] Lebedeva N.: Russ. J. Phys. Chem., 1964, 38, 1435.

[23] Van-Chin-San Yu. et al. (Eds.): Thermodynamichni Vlactivosti Kysenvmisnykh Organichnykh Spoluk. Dovidnyk. NULP, Lviv 2012.

Received: March 19, 2018/Revised: June 07, 2018 / Accepted: September 11, 2018

\section{МОЛЕКУЛЯРНЕ МОДЕЛЮВАННЯ ОКИСНЮВАЛЬНОЇ РЕАКЦІЇ АКРИДИНУ ПЕРОКСИКИСЛОТАМИ}

Анотація. Квантово-хімічними методами розраховано оптимальну геометричну будову та реакційну здатність деяких пероксикислот, акридину та продуктів їхньої взаємодії. Встановлено, щчо теплота утворення пероксикислот (ПК) $i$ карбонових кислот $(\mathrm{KK})$ збільшується із підвищенням довжини вуглеводневого радикалу. Залежності площ молекул ПК та молекул $K K$ від кількості атомів карбону в молекулах $\epsilon$ лінійними. Потенціали йонізації всіх досліджених ПК близькі $i$ знаходяться в діапазоні 11.22-11.39 еВ, залежно від методів розрахунку. Теоретично обчислені дипольні моменти кислот, акридинів, пероксикислот та $\mathrm{N}$-оксидів акридину непогано узгоджуються з експериментальними значеннями, щео вказуе на правильність розрахунків. Теоретично обчислені значення теплоти утворення $\left(\Delta H_{f}^{0}\right)$ пероксикислот та акридину непогано узгоджуються зі значеннями, отриманими термохімічними методами. Розрахунки показують, щэо розмір вуглеводневого радикалу практично не впливає на величину

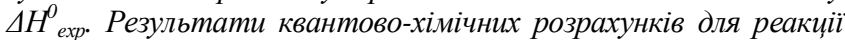
окиснення акридину можуть бути корисними для прогнозування інших механізмів окиснювальних процесів.

Ключові слова: пероксикислоти, квантово-хімічні розрахунки, реакиійна здатність окиснення, акридин, теплоти утворення. 